$\frac{\text { Jpn. J. Pharm. Health Care Sci. }}{\text { ノ }- \text { r } 29(5) 603-610(2003)}$

\title{
大学院博士前期課程における医療薬学実務研修に関する調査
}

\author{
松田裕子*，八木敬子，平井みどり \\ 神戸薬科大学臨床薬学研究室†
}

\section{A Survey of the Practical Training Included in Postgraduate Hospital Pharmacy Courses}

\author{
Hiroko Matsuda*, Keiko Yagi and Midori Hirai \\ Department of Clinical Pharmacy, Kobe Pharmaceutical University $\dagger$
}

\begin{abstract}
$\left[\begin{array}{l}\text { Received January 20, } 2003 \\ \text { Accepted May 31, } 2003\end{array}\right]$
Due to changes in the roles of pharmacists in the clinical field, a lengthening of the mandatory study period at pharmacy school is currently being considered. We therefore conducted a survey of the practical training included in the postgraduate hospital pharmacy courses with the aim of exploring the possible forms of the longterm practical training which may be necessary in the future. An analysis of eleven reports on practical training in hospitals and 46 questionnaires completed by students who had completed hospital training suggested that the acquisition of patient oriented pharmaceutical care, which is seen as one of the main aims of such training had, to a large extent, been successfully achieved, however, the ability to identify pharmaceutical problems in the clinical environment had not yet been adequately developed in most students. Most students considered hospital training to be a positive experience but also indicated problems regarding the curriculum, coordination between the university and the training institutions, and the resources of the training institutions. In order to educate fully capable pharmacists, closer coordination and cooperation between the universities and the medical treatment institutions is thus called for in future.
\end{abstract}

Keywords — postgraduate hospital pharmacy course, practical training, ability to identify pharmaceutical problems, curriculum

\section{緒 言}

医療の高度化に伴い，薬剤師教育のあり方についての 議論が活発化している. 医療の担い手の一員として生 命・健康の保持増進に寄与する責務を担う薬剤師を育成 する上で，病院・薬局等における実務研修は特に重要と 考えられるが，医師，歯科医師の教育と比較すると，薬 剂師教育では臨床現場における教育が著しく不足してい るのが現状である。

現在, 薬学部 4 年次学生に対する実務実習は必修化さ れる傾向にある，実習を受けた学生に対するアンケート
調査の結果, 実習期間は, 病院実習では $2 \sim 4$ 週間, 保 険薬局では $1 \sim 2$ 週間がほとんどで，実習内容に関して の学生の評価は概ね良好である。しかし, 一部, 施設側 の受け入れ体制の不備や, 施設間の実習内容の格差を指 摘する意見もみられる ${ }^{1,2)}$.

日本薬剤師会, 日本病院薬剂師会は, 21世紀の「医療 の担い手」としての薬剤師を養成するためには，医療薬 学実務実習の期間は 6 力月以上が必要との考えを示して おり, 薬学教育年限延長も検討されている3). 平成 14 年 8 月に日本薬学会より提示された薬学教育モデル・コア カリキュラムを実施する上でも，より多くの施設で，よ 
り長期にわたる実習生の受け入れが求められる。そのた め, 前述の施設側の受け入れ体制や, 施設間格差に関す る問題がより顕著になることが危惧される。

われわれは，実務研修に求められる大きな目的が，医 療現場における薬学的問題抽出能力の育成㧍よび, 患者 に対する医療人としての関わり方の体得にあると考え， 実務研修の現状を把握するとともに，これらの研修目的 の達成の有無を探るため, 現行の長期研修である, 大学 院博士前期課程に扔ける医療薬学実務研修報告書に関す る調査を実施した。さらに，研修内容の詳細を知る目的 で，研修修了生に対するアンケート調査を実施し，これ らの結果を分析するとともに, 今後の長期実務研修のあ り方を探り, 長期実務研修の施設に打けるカリキュラム 構築の一助とする目的で考察を加えた。

\section{方法}

1998～2001年度の大学院医療薬学専攻博士前期課程に 扮ける実務研修修了生による実務研修報告書を 6 大学か ら計11冊入手し(表 1), その内容について分析, 検討を 試みた。ささらに, そのうちの 3 大学につき, 研修内容の 詳細とその成果を調べる目的で, 研修修了生に対するア ンケート調查を実施した。アンケートの内容を図 1 に示 す。アンケートは無記名で, 3 大学, 72 名の研修修了生 を対象とした。対象の詳細㧍よび回収状況は表 2 に示 す.

\section{結果}

\section{1. 大学院医療薬学専攻博士前期課程研修修了生による 実務研修報告書の内容の分析}

大学院医療薬学専攻博士前期課程研修修了生に上る実 務研修報告書にみられる実務研修の概要を各大学院 1 冊 ずつを選んで調査し, その結果を表 3 に示す. 研修施設 は主に病院で, 実務研修期間は $3 \sim 8$ カ月間である. 約 1 力月の薬剂部研修の後, 病棟に配属される例が多い が, 医局に配属される例, 薬剤部内の各部署で順に研修 する例もある。また, 調剤薬局実習, 介護体験実習を取 り入れている例もあり, 大学, 研修施設により異なって いる. 課題研修, 研修報告会の実施形態も大学により異 なる。

11 冊の実務研修報告書に収載されているテーマは総数
175であった。これを内容別に分類し，図2に示す。報 告書収載のテーマとしては, 薬物治療の検討, 副作用 · 相互作用, 服薬指導などの観点からの症例検討が多い. また, 医薬品使用状況の実態調査や, 臨床薬理に関する 実験報告もみられた。疾患としてはペインコントロール への関わりから悪性腫瘍・慢性関節りウマチ, 患者教育 の重要性から喘息・糖尿病をとりあげたものが目立つ. 新薬や新しい治療法の検討もとりあげられている。これ らのテーマへのアプローチのしかたは, 症例研究が約半 数をしめ, デー夕の収集・解析も多い. また, 文献調査, 実験・試験によるものもみられる。

表 4 に, 報告書にみられる，医療現場での問題抽出例 とその対応を示す。

なお，実務研修報告書の内容に関する年度間の顕著な 差は認められなかった。

\section{2. アンケート調查の結果}

研修内容の詳細を知る目的で実施した研修修了生に対 するアンケートは図 1 に示す内容で，64\%の回答率を得 た(表2).

アンケート結果にみられる入院患者に対する研修体験 を図 3 に示す，入院患者の経過モニタ一, 薬物療法に対 する検討はほほ全員が体験していた。また，入院患者へ のインタビュー(服薬指導) は, 自ら患者を担当したも の, 指導薬剂師が同席して自ら実施したもの, 指導薬剤 師に同行して見学したものと, いずれかの形式で, 全員 が体験していた。

入院患者へのインタビュー(服薬指導)を自ら体験して の感想は，「患者をまかせられたので意欲的に取り組め た」(81\%)，「実施したことで自信がついた」(56\%)とい う回答が多かった。また「ひとりで実施するのは不安 だった」(44\%)，「もっと同席して実地指導してほしかっ た」(22\%),「もっと相談にのってほしかった」(11\%)と いう指導強化を求める声もあった。このほか, 「大変貴 重な経験をすることができた」,「患者さんが何を必要と しているのか痛切に感じられた」,「薬物以外の知識 (食 品, 栄養, 運動療法など)の必要性を感じた」, 「適切な ときにバックアップしてもらって助かった」などの感想 がみられた。患者をまかせられたので，責任が重く， 負担に感じた」( 8 \%)という消極的な回答もあったが,

表 1. 調査対象実務研修報告書

\begin{tabular}{|c|c|c|c|c|c|c|}
\hline 大学院名 & A大学院 & B大学院 & C大学院 & D大学院 & E大学院 & $\mathrm{F}$ 専攻科 \\
\hline 分類 & 私立 & 私立 & 私立 & 国立 & 国立 & 私立 \\
\hline \multirow{3}{*}{$\begin{array}{l}\text { 報告書調查年度 } \\
(* \text { : 表 } 3 \text { 示す概要 } \\
\text { 調查年度 })\end{array}$} & 平成 10 （1998) 年度 & 平成 1 O (1998) 年度 & "平成 1 1 (1999) 年度 & *平成 10 (1998) 年度 & *平成 11 (1999) 年度 & 平成 10 (1998) 年度 \\
\hline & *平成 $12(2000)$ 年度 & *平成 $12(2000)$ 年度 & *平成 $12(2000)$ 年度 & - & - & *平成 1 1(1999) 年度 \\
\hline & - & 平成 13 (2001) 年度 & - & - & - & - \\
\hline
\end{tabular}




$$
\text { 病院研修に関するアンケート }
$$

薬学教育年限延長を控え、薬剤師教育のあり方について議論がなされています。 我々は、中でも重要と考えられる病院研修のあり方について研究を行なっており ます。そこで、大学院修士課程で受けられました病院研修に関し、アンケート調 查を実施することにしました。以下の質問にお答えいただきますよう、ご協力を お願いいたします。

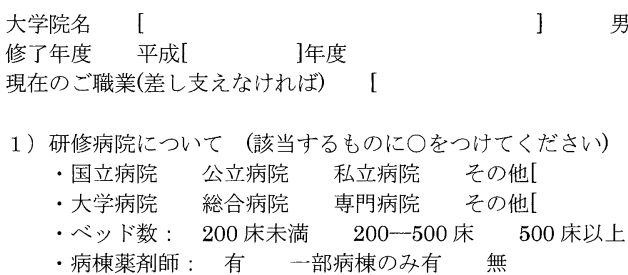

2) 研修中に次のことを体験されましたか（○をつけてください）
1. 入院患者の経過モニター
(はいいいえ)
2. 入院患者の薬物療法に対する検討
(はいいいえ
3. 入院患者の処方設計または処方変更への関与
(はいいえ)
4. 入院患者へのインタビュー (服薬指導)
(はいいいえ)

3) 研修中に入院患者へのインタビュー（服薬指導）を体験された方に どのように体験されましたか（番号に○をつけてください）

1．自ら患者を担当した（はじめは指導薬剂師が同席した場合を含む）

2. 常に指導薬剤師が同席して、自ら実施した

3. 指導薬剤師に同行して、見学した

4. その他 [

4) 入院患者へのインタビュー（服薬指導）を実施された（３）で 1 または 2 と答えられた）方に

研修を終えてどのような感想をもたれましたか

(番号に○をつけてください 複数回答可)

1. 患者をまかせられたので意欲的に取り組めた

2. 患者をまかせられたので、責任が重く、負担に感じた

3.ひとりで実施するのは不安だった

4.もっと同席して実地指導してほしかった

5.もっと相談にのってほしかった

6. 同席なしで実施したかった

7.実施したことで自信がついた

8. その他 [

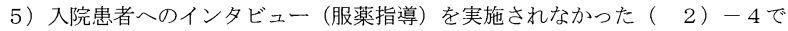
“いいえ”と答えられた方および 3）で3と答えられた）方に

ご意見をお聞かせください（番号に○をつけてください 複数回答可）

1. 患者へのインタビュー（服薬指導）を実施したかった

2. 実施するのは能力的に困難であるう

3. 実施するのは時間的、カリキュラム的に困難であろう

4. 見学だけで充分である

5. 患者へのインタビュー（服薬指導）を体験する必要はない

6. その他 [

6 ) 課題研修について

(課題が複数の場合は、研修報告書収載の課題についてお答えください)

・テーマ [

・上記のテーマはどのようにして決められましたか（番号に○をつけてくだ

さい)

1. 自ら提案した

提案した理由は 1 . 研修中に問題に遭遇した

2. 以前から興味があった

3. その他

2. 提案された

提案のされ方は 1 . 単数テーマを提示された

2. 複数テーマを提示され、その中から自ら選択

提案者は 1 . 指導医師

\section{2. 指導薬剤師}

3. 大学教員

4. その他 [

7 ) 病院研修からどのような成果が得られましたか

該当するものがあれば下記より選び、番号を記入してください 複数回答可

その他、自由にご記入ください

病棟研修と課題研修が分けにくい場合は片方の記入で結構です)

·薬剤部研修

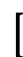

· 病棟研修

課題研修

[

. 研修全体

[

(1) 医療現場における薬剤師の実務がわかった

(2) 医療現場における他の医療従事者の実務がわかった

(3) 患者さんとの関わり方を学んだ

(4) 他のスタッフとの関わり方を学んだ

(5) 現場で生じる問題の薬学的なとらえ方を学んだ

(6) 大学で学んだことがらと現場との関連を学んだ

(7) 将来の進路を考える上で参考になった

8 ）病院研修で学んだことが、卒業後、役立っていますか（番号を記入してくだ さい)

·薬剤部研修 [

·病棟研修

・課題研修 [

(1)大変役立っている (2)やや役立っている （3)ほとんど役立っていない

(4)全く役立っていない

9 ) 薬学部が年限延長になった場合、病院研修は必要と思われますか(○をつけて ください)

1. ぜひ必要

2.できれば実施する方がよい

3. 不必要

4. その他 I

1 または 2 と答えられた方に

期間はどのくらいが適当と思われますか [

10 ）病院研修に関するご意見をおきかせください 大学に対して

病院に対して

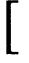

その他

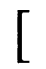

ご協力どうもありがとうございました 図 1.アンケート内容

概ね前向きで，よい経験として捉えられていた。また， 見学のみの者からは「自ら体験したかった」という声も
あった。

図 4 に示すように, 研修報告書収載のテーマの決め方 
表 2.アンケート調査対象および回収率

\begin{tabular}{|c|c|c|c|c|}
\hline & 研修年度 & 依頼数 & 回答数（うち在学中の者） & 回答率 \\
\hline \multirow{2}{*}{ A大学院 } & 平成 $10(1998)$ 年度 & 13 & $8(0)$ & \multirow{2}{*}{$73 \%$} \\
\hline & 平成 $12(2000)$ 年度 & 9 & $8(1)$ & \\
\hline \multirow{2}{*}{ B大学院 } & 平成 $12(2000)$ 年度 & 12 & $5(0)$ & \multirow[b]{2}{*}{$59 \%$} \\
\hline & 平成13 (2001) 年度 & 20 & $14(14)$ & \\
\hline \multirow{2}{*}{ C大学院 } & 平成11(1999)年度 & 8 & $6(0)$ & \multirow[b]{2}{*}{$61 \%$} \\
\hline & 平成12 (2000) 年度 & 10 & $5(0)$ & \\
\hline \multicolumn{2}{|c|}{ 合計 } & 72 & $46(15)$ & $64 \%$ \\
\hline
\end{tabular}

アンケート実施時期 平成14(2002) 年 4 月

実施対象 大学院医療薬学専攻博士前期課程 医療薬学実務 研修修了生

表 3．実務研修報告書にみられる病院研修概要

\begin{tabular}{|c|c|c|c|c|c|c|c|}
\hline \multicolumn{2}{|r|}{ 大学院名 } & A大学院 & $B$ 大学院 & $\mathrm{C}$ 大学院 & D大学院 & $\mathrm{E}$ 大学院 & $\mathrm{F}$ 専攻科 \\
\hline \multicolumn{2}{|r|}{ 分類 } & 私立 & 私立 & 私立 & 国立 & 国立 & 私立 \\
\hline \multicolumn{2}{|c|}{$\begin{array}{l}\text { 研修実施年次 } \\
\end{array}$} & 2 年次 & 1年次 & 1年次 & 1年次 & 1年次 & 1年 \\
\hline \multicolumn{2}{|r|}{ 研修期間 } & $\begin{array}{c}10 \text { 月〜 } 2 \text { 月 } \\
(5 \text { 力月 })\end{array}$ & $\begin{array}{c}10 \text { 月〜 } 2 \text { 月 } \\
(5 \text { 力月 })\end{array}$ & $\begin{array}{c}7 \text { 月〜 } 12 \text { 月 } \\
9 \text { 月〜 } 2 \text { 月 } \\
\text { ( } 6 \text { 力月) }\end{array}$ & $\begin{array}{c}5 \text { 月 8月 } \\
\text { ( } 3 \text { カ月以上 })\end{array}$ & $\begin{array}{c}10 \text { 月 } 3 \text { 月 } \\
(6 \text { 力月 })\end{array}$ & $\begin{array}{l}7 \text { 月〜 } 2 \text { 月 } \\
(8 \text { 力月 })\end{array}$ \\
\hline \multirow{3}{*}{$\begin{array}{l}\text { 研修 } \\
\text { 施設 } \\
\end{array}$} & 大学病院 & $11 \%$ & $100 \%$ & $40 \%$ & $100 \%$ & $64 \%$ & $25 \%$ \\
\hline & 総合病院 & $89 \%$ & $0 \%$ & $60 \%$ & $0 \%$ & $27 \%$ & $75 \%$ \\
\hline & その他の病院 & $0 \%$ & $0 \%$ & $0 \%$ & $0 \%$ & $9 \%$ & $0 \%$ \\
\hline \multirow{7}{*}{$\begin{array}{l}\text { 研 } \\
\text { 修 } \\
\text { 内 } \\
\text { 容 }\end{array}$} & 薬剂部 & 約 1 力月 & 約 1 力月 & $1 \sim 6$ 力月 & 約 3 力月 & \multirow{4}{*}{ 記載なし } & $1 \sim 7$ 力月 \\
\hline & 病棟業務 & 約 3 力月 & - & 1 週間〜 5 力月 & 約 3 力月 (見学実習) & & $5 \sim 6$ 力月 \\
\hline & 医局配属 & - & $1 \sim 3$ 力月 & - & - & & - \\
\hline & 他部署 & 見学実習 & 見学実習 & 見学実垍 & - & & 見学実習 \\
\hline & 調剤薬局 & - & 施設により研修あり & 施設により見学あり & - & 2 週間 & - \\
\hline & その他 & 介護体験 & - & - & - & - & - \\
\hline & $\begin{array}{l}\text { 研修報告書 } \\
\text { 収載のテー } \\
\text { マ }\end{array}$ & $\begin{array}{l}\text { 研修において特に着 } \\
\text { 目した内容をまと報告書 } \\
\text { る。その他、哉 } \\
\text { 収載テーマ別 } \\
\text { に、各自特別課題を } \\
\text { 決めてまとめる }\end{array}$ & $\begin{array}{l}\text { 指導医にテーマを与 } \\
\text { えられる、研修中に } \\
\text { 見出したテーマを自 } \\
\text { 由に選択する等、施 } \\
\text { 設により異なる }\end{array}$ & $\begin{array}{l}\text { 研中にテーマを与 } \\
\text { えられ、あるいは自 } \\
\text { ら問題点をみつけみ } \\
\text { 調査、研究、実験し } \\
\text { でとめる }\end{array}$ & \begin{tabular}{|l} 
研修中に課題を見出 \\
L、研修期閒終了後調 \\
査研究しまととるる
\end{tabular} & \begin{tabular}{|l|} 
指導薬鼡師と相談の \\
上、課題を選定し、 \\
研修学習
\end{tabular} & \begin{tabular}{|l} 
研修項目中、特に重 \\
点をおいた研修につ \\
き報告
\end{tabular} \\
\hline \multicolumn{2}{|r|}{ 研修報告会 } & $\begin{array}{l}\text { 二週間ごとに大学に } \\
\text { て。中間報告会は合 } \\
\text { 宿研修。最終報告会 } \\
\text { は大学にて公聴会形 } \\
\text { 式で。 }\end{array}$ & \begin{tabular}{|l} 
研修施設にて。 \\
(報告書提出のみの \\
施設もあり)
\end{tabular} & $\begin{array}{l}\text { 一週間ごとに大学に } \\
\text { て指導教員と討議。 } \\
\text { 最終報告会は大学に } \\
\text { て }\end{array}$ & 大学にて & 大学にて & $\begin{array}{l}\text { 各施設にて中間報告 } \\
\text { 会。最終報告会は、俢 } \\
\text { 大学または研修施設 } \\
\text { にて。 }\end{array}$ \\
\hline \multicolumn{2}{|r|}{ 調査年度 } & 平成12(2000) 年度 & 平成12(2000) 年度 & 平成12(2000) 年度 & 平成10(1998) 年度 & 平成11(1999)年度 & 平成11(1999)年度 \\
\hline
\end{tabular}

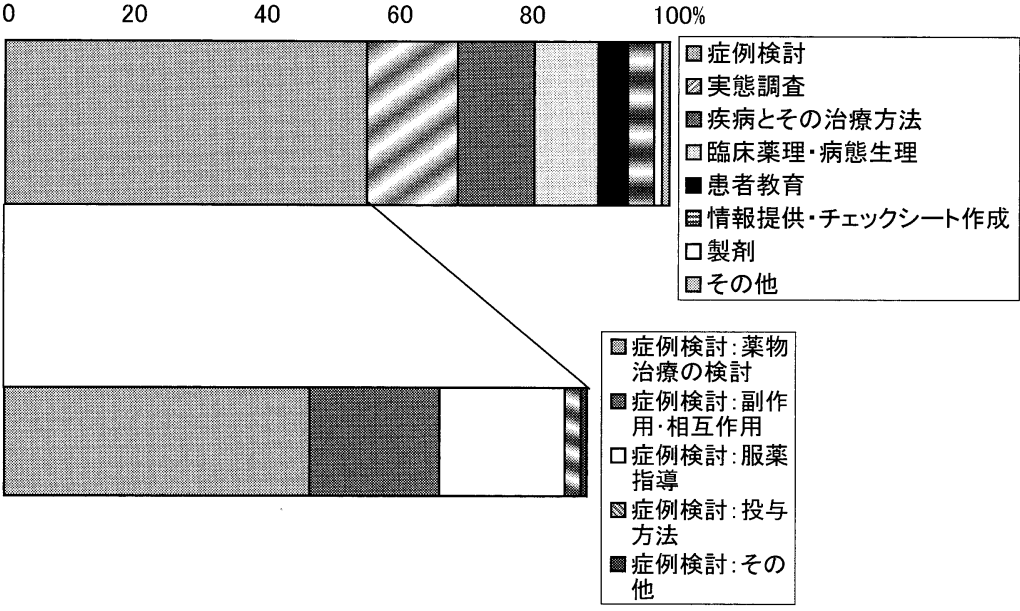

図 2. 報告書収載テーマの内容別分類 (テーマ総数：175) 
表 4. 報告書にみられる医療現場での問題抽出とその対応事例

\begin{tabular}{|c|c|c|}
\hline 背景 & 抽出した問題点 & 対応 \\
\hline 腎障害患者 & $\begin{array}{l}\text { 緊排泄型薬剤投与による副 } \\
\text { 作用発現 }\end{array}$ & $\begin{array}{l}\text { 医師への情報提供を行い、当該薬剈（３種類）の中止 } \\
\text { および投与量変更 }\end{array}$ \\
\hline プレドニゾロン服用患者 & \begin{tabular}{|l} 
副作用に対する不安からの \\
ハンコンプライアンス
\end{tabular} & $\begin{array}{l}\text { 服薬の必要性の説明。副作用に関する説明書および処 } \\
\text { 方薬の一責をを作成して副作用の予防と対策をくわし } \\
\text { く説明し、服薬に対する理解と積極性を得る }\end{array}$ \\
\hline $\begin{array}{l}\text { 気管支喘息患者に対する発 } \\
\text { 作時吸入楽の頻回処方 }\end{array}$ & $\begin{array}{l}\text { 患者の理解不足 (ステロイイ } \\
\text { ド吸入楽と同様と理解) }\end{array}$ & $\begin{array}{l}\text { ハンドネブライザー使用患者に対する使用実態のアン } \\
\text { ケート調查を実施後、吸入薬の正しい使用方法をまと } \\
\text { め、入患者に説明する }\end{array}$ \\
\hline $\begin{array}{l}\text { 糖尿病患者に対する服薬指 } \\
\text { 導 }\end{array}$ & 早朝高血糖 & $\begin{array}{l}\text { 早朝高血糖の実態調查を実施し、約 } 25 \% \text { \%゙経験して } \\
\text { いることが判明 (研修中に対策の経験にはたたらず) }\end{array}$ \\
\hline $\begin{array}{l}\text { ステロイドによる副作用発 } \\
\text { 現 }\end{array}$ & $\begin{array}{l}\text { ステロイド剤による軽度の } \\
\text { 副作用に関する資料がほと } \\
\text { んどない }\end{array}$ & $\begin{array}{l}\text { プレドニンの副作用チェックシートの作成。投与開始 } \\
\text { 後の日数によより登現しやすい副作用の把握が可能にな } \\
\text { り、服薬指導が効果的になった }\end{array}$ \\
\hline $\begin{array}{l}\text { 救急救命センターにおける } \\
\text { 高血圧緊急症患者の入院 }\end{array}$ & $\begin{array}{l}\text { 緊急状態にお打る迅速・適 } \\
\text { 场な降圧剂選択の重要性 }\end{array}$ & 各々の病態において使用される降圧郕を調査 \\
\hline 服薬指導 & $\begin{array}{l}\text { 薬剂師が使用する用語に対 } \\
\text { する患者の理解度に疑問 }\end{array}$ & $\begin{array}{l}\text { アンケート調查により、理解度の実態を把握し、患者 } \\
\text { にわかりやすい説明にする }\end{array}$ \\
\hline
\end{tabular}

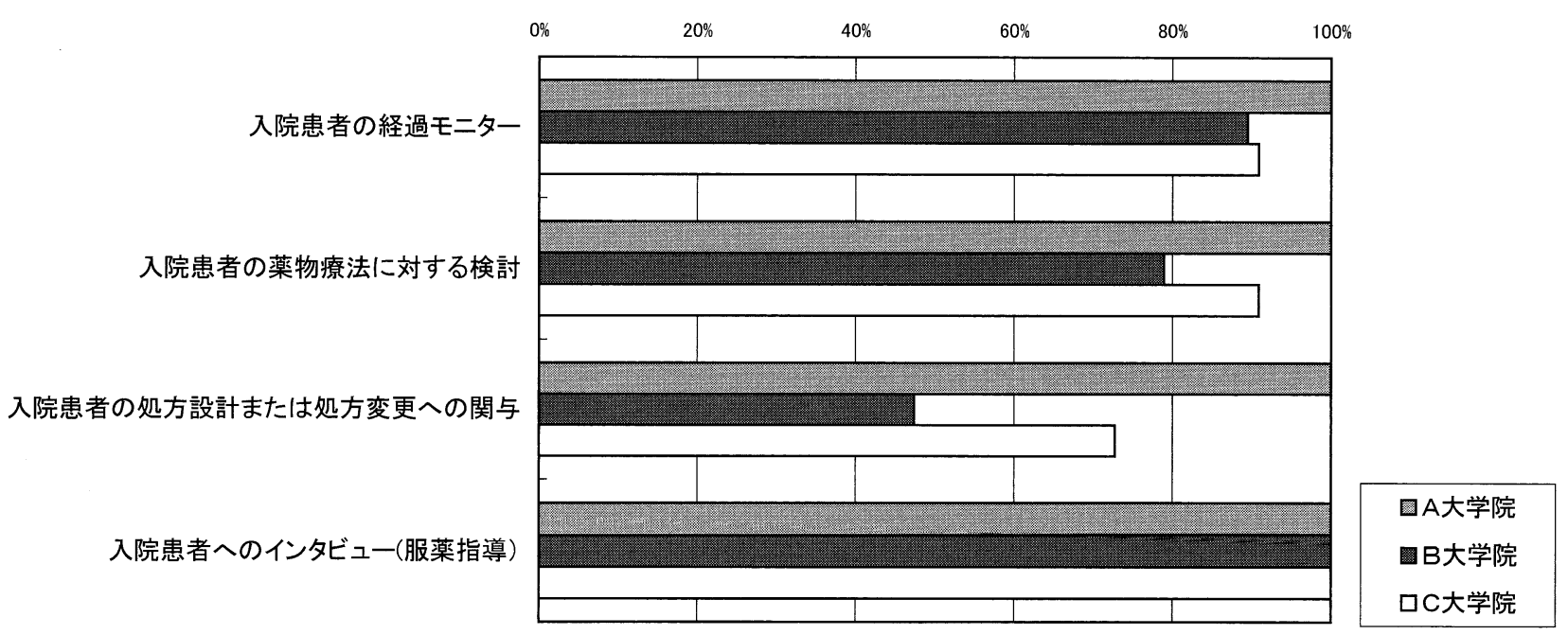

患者インタビュー(服薬指導)の体験のしかた

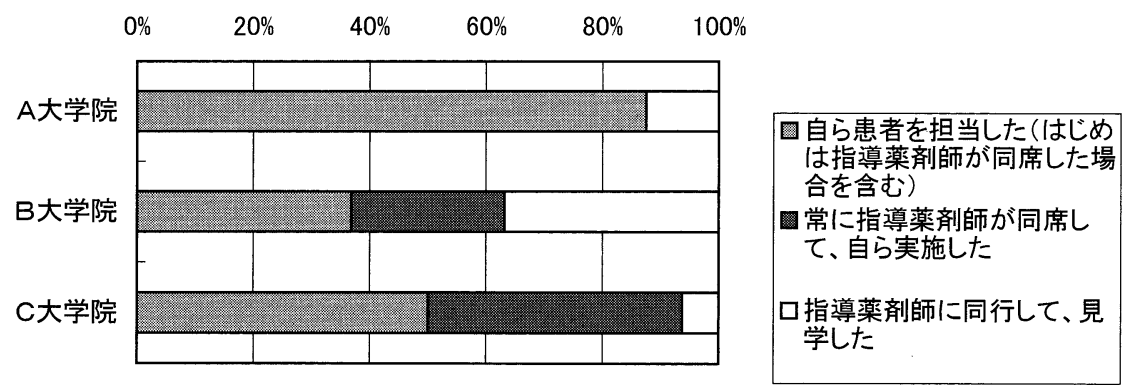

図 3. 入院患者に対する研修体験(回答数：46)

は, 大学, 施設により傾向が異なり, 半数以上の者がテー マを提示された大学もあった。自ら提案した者の多く
は，研修中に問題に遭遇した，あるいは以前から興味が あったとしている。 


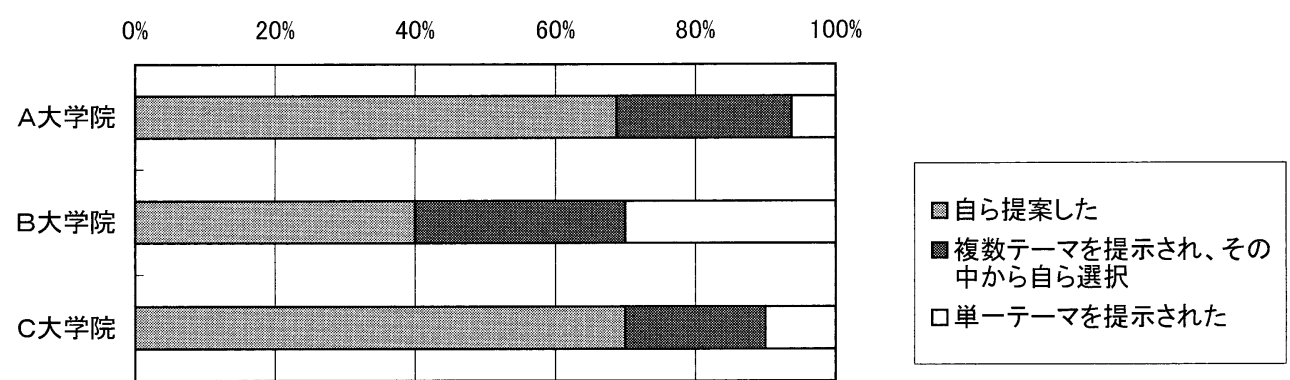

自ら提案したもののうちわけ

研修中に問題に遭遇した
以前から興味があった 认の前から
テーマの提示者

$\begin{array}{ll}\text { 指䆃医師 } & 52 \% \\ \text { 指嘎薬剂師 } & 35 \% \\ \text { 大学教員 } & 13 \%\end{array}$

図 4. 研修報告書収載テーマの決めかた（回答数：計45)

図 5 に病院研修から得られた成果を示す。大多数の者 は，医療現場に扮ける薬剤師や他のスタッフの実務がわ かったとしている．患者との関わり方，他のスタッフと の関わり方を学んだとする者も多い. 一方, 現場で生じ る問題の薬学的な捉え方，大学で学んだことがらと現場 との関連を学んだ，とする者は約40～70\%にとどまって いる.

研修に関しての研修修了生の意見として多くみられた ものを表 5 に示す。「大変よい経験となった」，「今後も ぜひ実施すべき」との感想が多く得られたが，大学，施 設問のより密接な連絡，受け入れ体制・カリキュラムの 整備等の改善を求める意見や，複数施設の体験あるいは 見学を希望する声もあった。

アンケート結果には, 既卒者, 在学者間の顕著な差は 認められなかった。

\section{考察}

医療現場における薬学的問題抽出能力の育成，患者に 対する医療人としての関わり方の体得は，実務研修の大 きな目的であると考える．研修報告書の内容を分析した 結果，表 4 に示すように，研修中に医療現場で問題を抽 出し，それに対応した例が認められた。しかし，報告書 の記述方式が各大学により異なることもあり，実際に修 了生の何割が現場で自ら問題を抽出できたのかを把握す ることはできなかった。また，報告書収載のテーマが, 自ら提案したものか，指導者から提示されたものかの判 断も困難であった．さらに，医療人としての患者との関 わり方，現場での薬剤師としてのあり方の体得の有無の 実態も把握が困難であった。そこで，研修内容の詳細と 研修の成果を調べる目的でアンケート調査を実施した。

アンケート調査の結果, 医療現場における問題の薬学
的捉え方や，大学で学んだことがらと現場との関連を学 んだ，とする者は約40～70\%にとどまっており，医療現 場における薬学的問題抽出能力の育成の面では十分な成 果をあげているとは言いがたい，問題抽出能力の育成の ためには Problem based Learning(PBL)が優れた手法であ るとされている4-7)。あらかじめ学内において PBLなど の手法を用いたプレ実習を実施し，問題を抽出しそれに 薬学的考察を加える演習を課すことは，その後の実務研 修において問題抽出能力を磨く上で有効であると考え る。また，研修報告書収載のテーマを自ら提案した者の 多くが，研修中に問題に遭遇した，あるいは以前から興 味があったとしており，問題抽出能力の体得がうかがわ れた。したがって，研修に際しては，指導教員あるいは 指導薬剤師は，安易にテーマを提示することなく，研修 生自らの問題点の抽出を待つ姿勢も求められよう。ま た，研修生が自ら体験し抽出した問題点への薬学的対応 については，現場の指導薬剤師のみならず，大学教員も 指導にあたることが必要と考えられる。

患者や他のスタッフとの関わり方の体得に関しては, 図 5 に示すようにほぼ達成されており，チーム医療に携 わる薬剤師を育成する上で実務研修が成果をあげている ことが認められる。患者へのインタビュー(服薬指導)を 自ら実施したか否かの，患者との関わり方の体得に対す る影響を検討した。患者へのインタビュー(服薬指導)を 自ら実施した者36名のうち，患者との関わり方を学んだ と回答した者は33名であり，見学のみの者10名のうち患 者との関わり方を学んだと回答した者は 7 名であった。 サンプル数が少ないため，フィッシャーの直接確率計算 法を用いて検定すると, p 值は0.1066である。また，オッ ズ比は 4.7 となった。このことから，有意差は認められ ないが，患者へのインタビューを見学ではなく自ら体験 


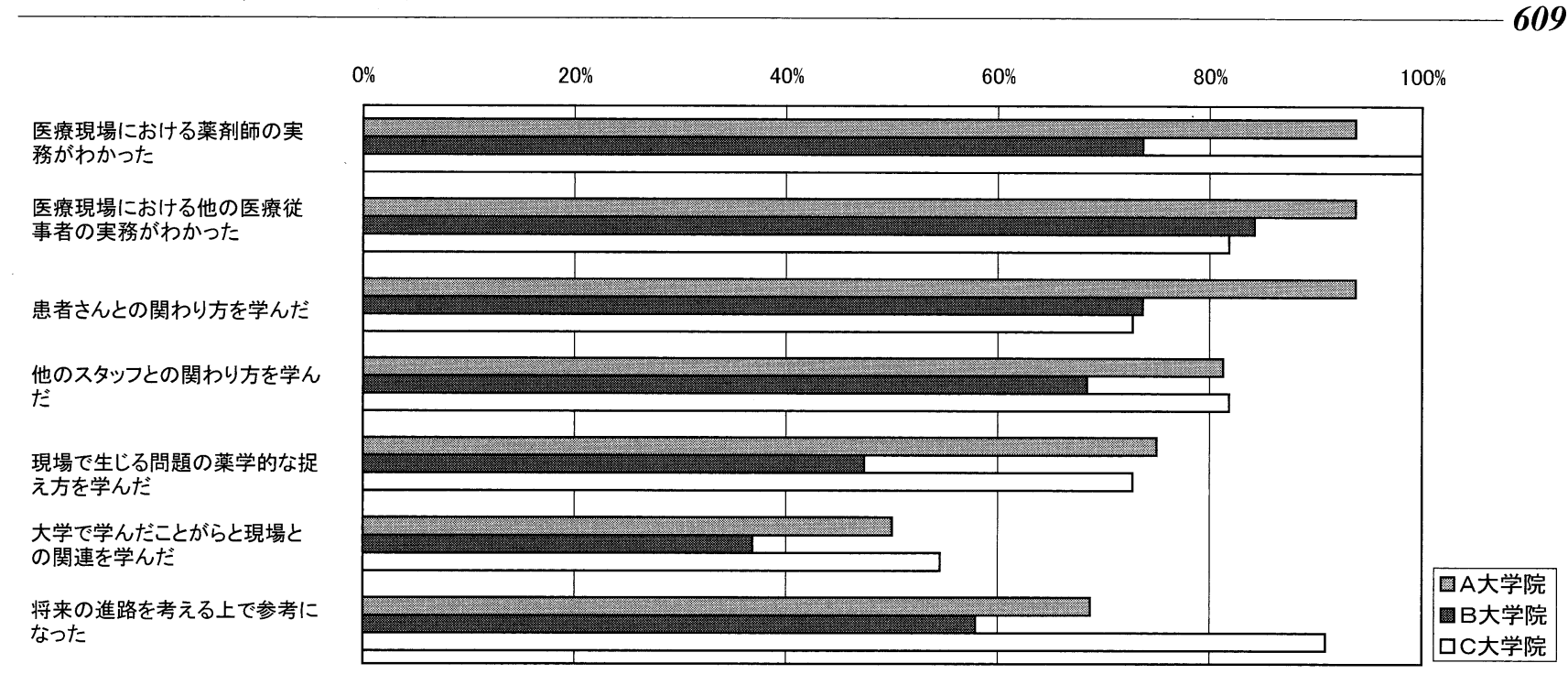

\section{その他の意見}

•すばらしい経験ができた。薬剤師としての自覚を学んだ

·病院内での自分の立場、できること、できないこと、すべきことなど考える習慣がついた

・患者の全体像の把握のしかたを学んだ。処方薬剤で疾患を追えるようになった

·医師の考え方を知る貴重な体験ができた

·今後の病院薬剤師のあり方を考えることができた

·医療の理想、大学で学んだことと現実のギャツプを強く感じた

·薬剤師の現状での限界を感じ、現在の境遇の改善を考えさせられた

·教科書の内容について現実感を得た

図 5. 病院研修によって得られた成果

\section{表 5. 研修に関しての意見，感想}

\begin{tabular}{|c|c|}
\hline $\begin{array}{l}\text { 大 } \\
\text { 学 } \\
\text { L } \\
\text { 対 } \\
\text { 乙 }\end{array}$ & $\begin{array}{l}\text { 病院との連絡をもっと密にしてほしい } \\
\text { 研修施設選定時、施設の力量を考慮してほしい } \\
\text { 研修目的を明確に提示してほしい } \\
\text { 研修カリキュラムを確立してほしい } \\
\text { 研修期間をもっと長くしてほしい } \\
\text { 事前指導、助言をしてほしい } \\
\text { 修士論文との両立が困難である } \\
\text { 希望する進路により研修期間の考慮をしてほしい }\end{array}$ \\
\hline $\begin{array}{l}\text { 病 } \\
\text { 院 } \\
\text { 詨 } \\
\text { ᄂ } \\
\tau\end{array}$ & $\begin{array}{l}\text { 研修のための環境づくり、受け入れ体制の整備をしてほしい } \\
\text { カリキュラムに工夫してほしい } \\
\text { 複数の病棟を経験したい } \\
\text { 他の部署の見学をしたい } \\
\text { 医師の指導を受けられたのがよかった } \\
\text { もっとアドバイスをしてほしかった } \\
\text { 大学との連絡をもっと密にしてほしい } \\
\text { 研修生が労働力としてしかみられていない } \\
\text { 指導薬剤師の養成をしてほしい }\end{array}$ \\
\hline $\begin{array}{l}\text { 研 } \\
\text { 修 } \\
\text { 全 } \\
\text { 体 }\end{array}$ & $\begin{array}{l}\text { 上い経験になった } \\
\text { ぜひ実施すべきである } \\
\text { 複数の施設を経験したい } \\
\text { 社会とのずれ、理想と現実とのずれを感じた } \\
\text { 病院、大学に精通した薬片師が必要である }\end{array}$ \\
\hline
\end{tabular}

すること，すなわち，診療見学型ではなく診療参加型の 研修が患者との関わり方を体得する上で有用であること
が示唆された．診療参加型の研修の前提として，患者と 円滑にコミュニケーションをはかる能力が要求される. このため, 学内でのプレ実習でコミュニケーション能力 をある程度身に付けておくことが必要である。

アンケートにより抽出された研修修了生の研修に関し ての意見では，研修カリキュラムの確立や工夫が求めら れ，大学と研修施設の連携に関する問題点が指摘されて いるとともに, 薬学部 4 年次学生に対する調査結果 ${ }^{1,2)}$ と同様, 研修施設の力量, 受け入れ体制の不備も指摘さ れている.

医療現場における業務量，薬剤師の人員および指導能 力等，長期にわたる研修生受け入れに対する阻害要因は 考えられるが，研修生受け入れにより，受け入れ施設に おける日常業務や他部署との連携の見直し等, 業務改善 のきっかけとなる可能性も十分考えられる。 さらに, 多 くの施設で受け入れることにより，現場の薬剤師全体の 意識改革や資質向上も期待できる. 社会から求められて いる薬剤師業務を遂行する能力をもつ薬剂師を育成する 上で, 現場の薬剤師の積極的な協力が強く求められる.

大学側も, 医療現場の声を聞き現状を理解した上で, 研修施設との役割分担をはかるとともに，研修の進渉状 況を常に把握し, 必要に応じて研修生への指導や助言を 行う等, きめ細かな対応が求められよう。また, 指導薬 
剤師の講習の場を設けるなどして, 研修施設の力量の向 上，質の確保をはかることが重要である．日本薬学会か ら提示されたコアカリキュラムの実施の上でも，施設に おける実務研修への，今まで以上の大学教員の関わりが 必要であり, 大学と研修施設が緊密な連携をはかりつ つ，ともに薬剤師を育成していく姿勢が求められている ものと考える.

謝辞＼cjkstart実務研修報告書のご提供をいただきました，徳島大 学薬学部, 岡山大学薬学部, 東京薬科大学, 名城大学薬学部, 福山大学薬学部, 神戸薬科大学に感謝いたします. また, ア ンケート調査にご協力いただきました福山大学薬学部医療薬 剂学研究室吉富博則教授, 各大学院実務研修修了生の皆様に 感謝いたします。

\section{引用文献}

1）乾賢一，病院・薬局実務実習に対する学生側の評 価, ファルマシア，37，907-911(2001).

2）伊賀立二, 乾賢一, 日本薬学会に拈ける医療薬学 への取組み一病院実務実習に対する学生側へのア
ンケート調査から一, 月刊薬事，42，491-501 (2000).

3）矢後和夫，薬剤師の卒前実務実習はどうあるべき か一病院実務実習について一, 月刊薬事, 43, 14891491 (2001).

4）西口工司，賀川義之，小島康生，H. Joseph Byrd, 鍋島俊隆，奥村勝彦，米国ミシシッピ大学におけ るファーマシューティカル・ケアー 2 一臨床薬剤 師の育成一, 日病薬誌，38，341-344(2002).

5）川上純一, 三村泰彦, 足立伊佐雄, 竹口紀晃, 大 学院臨床薬学教育における Personal Drug(P-Drug) セミナーの導入, 薬学雑誌, 122, 819-829(2002).

6) T.P.G.M. De Vries, R.H. Henning, H.V. Hogerzeil, J.S. Bapna, L. Bero, K.K. Kafle, A.F.B. Mabadeje, B. Santoso, A.J. Smith, Impact of a short course in pharmacotherapy for undergraduate medical students: an international randomised controlled study, Lancet, 346, 1454-1457 (1995).

7) R.E. Vestal, N.L. Benowitz, Workshop on problem based learning as a method for teaching clinical pharmacology and therapeutics in medical schools, $J$. Clin. Pharmacol., 32, 779-797(1992). 